\title{
Exploring the link between anabolic-androgenic steroids abuse for performance improvement and hepatocellular carcinoma: a literature review
}

\author{
Explorando a relação entre hepatocarcinoma e o abuso de esteroides anabolizantes \\ para otimização da aptidão física: uma revisão de literatura \\ Rafael Corrêa Coelho1', Gustavo dos Santos Fernandes², Cinthya Sternberg3.
}

\begin{abstract}
Introduction: Hepatocellular carcinoma (HCC) corresponds to $90 \%$ of primary malignant liver cell carcinomas and is a leading cause of cancer-related death worldwide. Objective: This compilation of cases aimed to identify evidence of correlation between anabolic androgen steroids (AAS) abuse for performance improvement by healthy subjects and HCC. Methods: We performed a literature review and identified 935, 1148, 12 and 3 articles in Pubmed, Embase, Scopus and Lilacs, respectively. Only studies, reviews and case reports evaluating the association between androgens and hepatocarcinoma were included with no restrictions in time span or language. Further on, we excluded studies and case reports which patients were receiving therapeutic androgens and collected data only of those reporting androgen intake to improve physical performance. Results: Six articles fulfilled the inclusion criteria, excluding the duplicates. HCC onset after AAS abuse seems to occur at earlier ages than those related to chronic hepatitis B/C, chronic alcohol consumption and nonalcoholic steatohepatitis (NASH). Timeframe ranged from two to seven years in the cases reports presented here. Many AAS subtypes were used by patients depicted in the case reports, so it is difficult to conclude if a specific AAS is safer or more harmful than the other. Carcinogenic mechanisms are poorly understood, but pre-clinical evidence shows that androgen receptors and oxidative stress may play a pivotal role in its development. Conclusion: The evidence that HCC has been linked to long term AAS abuse for performance improvement is scant but some association is suggested. AAS must be taken only under specialized supervision and the putative correlation with HCC calls for public policies to make high risk populations aware of the risks of misuse and self-administration.
\end{abstract}

Keywords: Hepatocellular carcinoma; Anabolic androgen steroids; Testosterone congeners

1. Hemato-Oncology Department, Hospital Universitário de Santa Maria, Santa Maria, Rio Grande do Sul, RS, Brazil.

2. Hospital Sirio-Libanês, Brasília, DF, Brazil.

3. Graduate Program of Anatomical Pathology, Faculty of Medicine, Universidade Federal do Rio de Janeiro, Rio de Janeiro, RJ, Brazil. Conflicts of interest: No

Correspondence author: : Rafael Corrêa Coelho. Hemato-Oncology Department, Hospital Universitário de Santa Maria, Avenida Roraima 1000, Prédio 22 Santa Maria, RS, Brazil. Zip code: 97105-340. Phone: +55 5532131870 E-mail: rccmed@gmail.com

Received on: December 20, 2017 | Accepted on: March 23, 2018

DOI: $10.26790 / B J O 20181447$ A175 


\section{RESUMO}

Introdução: O hepatocarcinoma $(\mathrm{HC})$ corresponde a 90\% das neoplasias malignas primárias do fígado, sendo uma importante causa de morte relacionada a neoplasias no mundo. Objetivo: Esta compilação de casos tem como intenção identificar uma possível correlação entre hepatocarcinoma e o abuso de esteroides anabolizantes (EA) para otimização da aptidão física em indivíduos saudáveis. Métodos: Foi realizada uma revisão de literatura na qual se identificaram 935, 1148, 12 e 3 artigos no Pubmed, Embase, Scopus e Lilacs, respectivamente. Foram incluídos, inicialmente, apenas estudos clínicos, revisões de literatura e relatos de caso avaliando a associação entre EA e HC, sem restrições quanto ao período e linguagem. Excluíram-se os estudos clínicos e os relatos de caso nos quais os pacientes receberam EA com objetivo terapêutico, sendo, portanto, coletados dados apenas dos artigos reportando o uso de EA para melhora da aptidão física. Resultados: Seis artigos preencheram os critérios de inclusão, excluindo-se as duplicações. $\mathrm{O}$ surgimento de $\mathrm{HC}$ após abuso de EA parece ocorrer em idades mais precoces quando se compara com o $\mathrm{HC}$ relacionado aos vírus da hepatite $\mathrm{B}$ e $\mathrm{C}$, consumo crônico de álcool e esteato-hepatite não alcoólica (NASH). O intervalo para surgimento da neoplasia a partir do início do abuso de EA variou entre 2 a 7 anos nos relatos de caso descritos nesta revisão. Diversos tipos de EA foram utilizados pelos pacientes descritos nos relatos de caso, o que torna difícil qualquer conclusão sobre qual EA teria um maior perfil de segurança ou risco. Os mecanismos de carcinogênese são pouco conhecidos, mas evidências pré-clínicas sugerem que os androgênios e o estresse oxidativo podem estar diretamente relacionados ao desenvolvimento de HC. Conclusão: As evidências relacionando HC e o abuso de EA para otimização da aptidão física são escassas, contudo os dados presentes da literatura sugerem que algum grau de associação é possível. EA devem ser utilizados apenas sob supervisão especializada e a possibilidade de haver uma associação com $\mathrm{HC}$ reforça a necessidade de políticas públicas para alertar às populações de maior risco sobre os perigos do uso incorreto e sem supervisão de esteroides anabolizantes.

Descritores: Carcinoma hepatocellular; Esteroides andrógenos anabólicos; Congêneres da testosterona

\section{INTRODUCTION}

Hepatocellular carcinoma (HCC) corresponds to $90 \%$ of primary malignant liver cell carcinomas and is a leading cause of cancer-related death worldwide. The prevalence of HCC is higher in males than in females (2.4:1), as well the incidence in Eastern and Southern Asia, Middle and Western Africa, Melanesia and Micronesia/Polynesia. ${ }^{(1,2)}$

Many different etiological factors are involved in the development of HCC as chronic hepatitis B/C, chronic alcohol consumption, nonalcoholic steatohepatitis (NASH) and aflatoxin exposure. ${ }^{(1-3)}$ Less common factors are long-term use of oral contraceptives and high-dose anabolic androgenic steroids. ${ }^{(1,3)}$
The association between androgen exposure and the development of HCC was first reported by Recant and Lacy in 1965 in a male patient with Fanconi's Anemia. Since this publication, several clinical reports have been published linking long term androgen exposure to HCC in Fanconi's and non-Fanconi's patients. ${ }^{(4,5)}$

Anabolic androgen steroids (AAS), synthetically produced hormones analogs to male testosterone, are commonly misused and self-administrated by healthy subjects to enhance physical performance. This independent practice raises concerns because the majority of users are not aware of their potential life threatening risks. ${ }^{(6,7)}$ 
This compilation of published case reports aims to identify evidence linking anabolic-androgen steroids abuse for physical performance improvement in healthy subjects and hepatocellular carcinoma.

\section{METHODS}

We performed a literature review searching in PubMed, Embase, Scopus and Lilacs databases using the following key words: 'liver cell carcinoma'/exp OR 'carcinoma, hepatic cell' OR 'carcinoma, hepatocellular' OR 'carcinoma, liver' OR 'carcinoma, liver cell' OR 'hepatic carcinoma' OR 'hepatic cell carcinoma' OR 'hepatocarcinoma' OR 'hepatocellular carcinoma' OR 'hepatoma' OR 'liver carcinoma' OR 'liver carcinoma rupture' OR 'liver cell carcinoma' OR 'malignant hepatoma' OR 'primary liver carcinoma' AND ('anabolic agent'/exp OR 'anabolic agent' OR 'anabolic agents' OR 'anabolic drug' OR 'anabolic hormone' OR 'anabolic steroid' OR 'anabolic steroid agent' OR 'anabolic steroids' OR 'anabolizing agent' OR 'anabolizing cream' OR 'anabolizing drug' OR 'anabolizing treatment' OR 'steroid, anabolic' OR 'androgen'/exp OR 'androgen' OR 'androgen sulfate' OR 'androgen sulphate' OR 'androgenic agent' OR 'androgenic hormone' OR 'androgenic steroid' OR 'androgens' OR 'androgens, synthetic').
We have identified 935, 1148, 12 and 3 articles in Pubmed, Embase, Scopus and Lilacs, respectively. Last literature research was performed on 27th December, 2017. The three authors searched independently in databases. Only studies, reviews and case reports evaluating the association between androgens and hepatocarcinoma were included with no restrictions in time span or language. Further on, we excluded studies and case reports which patients were receiving therapeutic androgens and collected data only of those reporting androgen intake to improve physical performance.

Six articles fulfilled these inclusion criteria, excluding the duplicates. For general purposes, we included conceptual studies evaluating the link between androgens and HCC.

\section{RESULTS}

The review of literature identified 6 case reports linking anabolic androgen steroids uses for enhancing physical performance and hepatocellular carcinoma.
(Table 1) No clinical trials or retrospective studies regarding the subject were found.

\section{DISCUSSION}

Historically, the use of anabolic steroids dates back to World War II when they were provided to German soldiers in order to enhance their aggressiveness. Since then, anabolic steroids have become increasingly popular amongst athletes, so much so, that steroid use in both professional and amateur athletics has reached epidemic proportions. In the late 1950s, Ciba Pharmaceuticals introduced methandrostenolone.(14-17) which would become the most popular anabolic drug for athletes. By this time, the era of the steroid athletes was well underway and world records were being shattered and re-shattered with remarkable regularity. ${ }^{(15)}$ Nowadays, this practice is controlled by specialized agencies, but despite the increased surveillance, it is still a concern in sports.

Estimates of the extent of steroid use among intercollegiate male athletes range from $2 \%$ to $20 \%{ }^{(17-20)}$ Two-thirds of AAS abusers start by the age of 16 years ${ }^{(18)}$ and the main reasons for using steroids are to increase strength and size, improve physical appearance, enhance athletic and sexual performance. (21) In Brazil, the unsupervised use of AAS is a reality and a risk not only for HCC and hepatic adenoma (HCA), but also for fatty liver disease. ${ }^{(22)}$ 
Table 1. Case reports of hepatocellular carcinoma after long term anabolic androgen steroids use for performance enhancement in healthy subjects

\begin{tabular}{|c|c|c|c|c|c|c|c|}
\hline Age & Sex & $\begin{array}{l}\text { Androgen, } \\
\text { Duration }\end{array}$ & $\begin{array}{c}\text { Patient } \\
\text { characteristics }\end{array}$ & Alfa-fetoprotein & $\begin{array}{l}\text { Pathology and } \\
\text { management }\end{array}$ & Outcomes & References \\
\hline $26 y$ & M & $\begin{array}{l}\text { Four years taking one or more } \\
\text { androgens: methandrosteno- } \\
\text { lone, oxandrolone, stanozolol, } \\
\text { nandrolonedecanoate, and } \\
\text { methenolone. }\end{array}$ & $\begin{array}{l}\text { Bodybuilder } \\
\text { This patient } \\
\text { also had a } \\
\text { cholangio } \\
\text { carcinoma }\end{array}$ & $375 \mathrm{ng} / \mathrm{mL}$ & $\begin{array}{l}\text { Pleural and liver } \\
\text { biopsies were } \\
\text { performed. Patient } \\
\text { refused treatment. }\end{array}$ & $\begin{array}{l}\text { Near total liver } \\
\text { replacement by } \\
\text { tumor and } \\
\text { pleural, } \\
\text { pulmonary and } \\
\text { intraabdominal } \\
\text { metastases. Died } \\
4 \text { months after } \\
\text { diagnosis. }\end{array}$ & $\begin{array}{l}\text { Overly et } \\
\text { al, 1984. }{ }^{(8)}\end{array}$ \\
\hline $37 y$ & $M$ & $\begin{array}{l}\text { Five years taking, firstly, } \\
\text { methandrostenolone and, after, } \\
\text { oxymetholone. }\end{array}$ & Athlete & NA & $\begin{array}{l}\text { Liver biopsy followed } \\
\text { by tumor resection. } \\
\text { Tumor with } 1.8 \mathrm{Kg} \text {. }\end{array}$ & NA & $\begin{array}{l}\text { Goldman } \\
\text { B, 1985.(9) }\end{array}$ \\
\hline $35 y$ & M & $\begin{array}{c}\text { Two years taking one or more } \\
\text { androgens: testosterone, stano- } \\
\text { zolol,nandrolonedeconat }\end{array}$ & Bodybuilder & Normal & $\begin{array}{l}\text { Right hemi-hepatec- } \\
\text { tomy for a tumor with } \\
\qquad 70 \times 90 \mathrm{~mm} \text {. }\end{array}$ & NA & $\begin{array}{l}\text { Gorayski } \\
\text { et al, } \\
2008 .^{(10)}\end{array}$ \\
\hline $37 y$ & $M$ & $\begin{array}{l}\text { Five years taking one or more } \\
\text { androgens: } \\
\text { Testosterone propionate, } \\
\text { testosterone phenylpropiona- } \\
\text { te,testosteroneisocaproate, } \\
\text { testosteronedecanoate,- } \\
\text { trenboloneacetate, 5alpha- } \\
\text {-androstanediol,boldenone } \\
\text { and methandrioldipropionate, } \\
\text { 17a-Methyl-5a-androstano[3,- } \\
\text { 2-c]pyrazole-17ß-ol, 17ß-hy- } \\
\text { droxy-17a-methyl-2-oxa-5a-an- } \\
\text { drostane-3-one, oxymetholonor } \\
\text { methandienone. }\end{array}$ & Bodybuilder & Normal & $\begin{array}{l}\text { Partial hepatectomy } \\
\text { for a tumor with } \\
60 \times 60 \times 50 \mathrm{~mm} \text {. }\end{array}$ & $\begin{array}{l}\text { After a follow-up } \\
\text { period of } 27 \text { mon- } \\
\text { ths there were no } \\
\text { recurrence signs. }\end{array}$ & $\begin{array}{l}\text { Hardt et } \\
\text { al, 2012.(11) }\end{array}$ \\
\hline $24 y$ & $M$ & $\begin{array}{l}\text { Seven years of testosterone } \\
200 \mathrm{mg} / \text { week. }\end{array}$ & Bodybuilder & 366 ng/mL & $\begin{array}{c}\text { Liver biopsy was } \\
\text { performed. The two } \\
\text { biggest lesions had } \\
111 \times 105 \mathrm{~mm} \text { (right } \\
\text { lobe) and } 79 \times 72 \mathrm{~mm} \\
\text { (left lobe). }\end{array}$ & NA & $\begin{array}{l}\text { Kesler et } \\
\text { al, 2014 } \\
\text { (12) }\end{array}$ \\
\hline $29 y$ & $M$ & $\begin{array}{l}\text { Six years taking one or more } \\
\text { androgens: nandrolone } \\
\text { decanoate, sustanon, } \\
\text { methandienone, stanozolol. }\end{array}$ & Bodybuilder & NA & $\begin{array}{l}\text { Liver biopsy followed } \\
\text { by liver } \\
\text { transplantation. }\end{array}$ & $\begin{array}{l}27 \text { months after } \\
\text { liver transplanta- } \\
\text { tion he is in ex- } \\
\text { cellent condition } \\
\text { without any signs } \\
\text { of metastasis or } \\
\text { local recurrence. }\end{array}$ & $\begin{array}{l}\text { Solbach et } \\
\text { al, 2015. }{ }^{(13)}\end{array}$ \\
\hline
\end{tabular}


The scarcity of data in the literature linking HCC and AAS in healthy patients for performance improvement might be due to the abnormal development of HCC after AAS usage, underdiagnosis and/or underreported cases.

Hepatocarcinoma onset after AAS abuse seems to occur at earlier ages than HCC triggered by chronic hepatitis B/C, chronic alcohol consumption and nonalcoholic steatohepatitis (NASH). ${ }^{(8-13)}$ HCC outbreak is also time-dependent and long term usage appears to be required for HCC development and timeframe for onset ranged from two to seven years in the cases reported in this literature review. However, it is important to stress that despite HCC being probably a late complication of continuous AAS use, much other life threatening complications can occur earlier on, so unsupervised AAS usage is a high risk strategy and not recommended to any healthy subjects.(7) Table 2 describe the main complications of AAS continuous exposure.

Table 2. Adverse events related to anabolic androgen steroids. ${ }^{(7,22)}$

\begin{tabular}{|c|c|}
\hline \multicolumn{2}{|c|}{ Adverse events } \\
\hline Cardiovascular & Neuropsychiatric \\
\hline Coronary heart disease & Reduced inhibitory control \\
\hline Cardiomyopathy & Anxiety \\
\hline Erythrocytosis & Aggression, violence, impulsive behavior \\
\hline Hemostasis/coagulation abnormalities & Depression \\
\hline Dyslipidemia & Hypomania and, occasionally, frank mania \\
\hline Hypertension & Dependence \\
\hline Atherosclerosis & Men \\
\hline Arrhythmia & Hypogonadism \\
\hline Anatomic remodeling & Testicular atrophy \\
\hline Infection & Gynecomastia \\
\hline $\begin{array}{l}\text { HIV, hepatitis B and C, MRSA } \\
\text { (unsafe needle practices and contaminated products) }\end{array}$ & Suppression of spermatogenesis \\
\hline Musculoskeletal & Impaired fertility \\
\hline Tendon rupture & Acne \\
\hline Amyotrophic lateral sclerosis & Premature epiphyseal closure \\
\hline Women & Potential increased risk for prostate cancer \\
\hline Acne & Renal \\
\hline $\begin{array}{l}\text { Virilization } \\
\text { (hirsutism, deepening of voice, clitoromegaly) }\end{array}$ & Renal insufficiency \\
\hline Irregular menses & Proteinuria \\
\hline Hepatic & Nephrotic syndrome \\
\hline \multicolumn{2}{|l|}{ Fatty liver disease } \\
\hline \multicolumn{2}{|l|}{ Cholestasis } \\
\hline \multicolumn{2}{|l|}{ Peliosis hepatis } \\
\hline \multicolumn{2}{|l|}{ Hepatic adenoma } \\
\hline Hepatocarcinoma & \\
\hline
\end{tabular}

Hepatocellular carcinoma is more prevalent in men than in women and one of the reasons for this difference could be related to testosterone and androgen receptor (AR) activities. ${ }^{(2,23,24)}$ Human epidemiological studies have shown that elevated testosterone levels and the presence of genetic polymorphisms linked to increased androgen activity were significantly associated with a higher risk of HCC in male HBsAg carriers. $^{(24-26)}$ In rodent HCC models, castration, treatment with anti-androgen agents and modulation of 
AR can protect male rodents from tumor development. (27,28) This evidence suggest that up-regulation of the androgen pathway signaling in male patients is able to accelerate the carcinogenic process in hepatocytes $\cdot(24,27,28)$

AAS subtypes seem to induce distinct liver damage; e.g.17a-alkylated AAS appear to be hepatotoxic whereas non-alkylated AAS is not. The 17a-alkyl substitution delays hepatic metabolism of the AAS, rendering it orally bioavailable. The main mechanism responsible for the hepatotoxicity induced by 17a-alkylated AAS is probably induction of oxidative stress, because it has repeatedly been shown to be associated with this biochemical pathway. ${ }^{(29)}$ However, not only oral androgens may induce hepatic neoplasms but also parenteral ones. ${ }^{(5,8-13)}$ As several AAS subtypes were used by subjects in case reports, it is difficult to conclude or estimate if a particular AAS is safer than the other.

Since 1965, when the first case report correlating HCC and AAS was published, HCC became a significant concern for patients undergoing long term treatment with androgens, especially those afflicted by hematological diseases as Fanconi's Anemia (FA). ${ }^{(5)}$ These patients have a strict follow up to their physicians, which include liver imaging to detect any lesions at early stages, allowing effective interventions when needed. Blood markers efficacy is questionable, since alpha-fetoprotein rarely deviates from baseline in early stage disease and liver enzymes may not raise to pathologic levels until death is imminent and unpreventable. ${ }^{(6,30)}$ The alpha-fetoprotein levels were shown to be high only in two case reports described in this review; the first patient had metastatic disease and the second locally advanced disease. Therefore, these findings are in line with literature ${ }^{(6,30)}$ and they suggest that this biomarker could be an indicator of disease burden and, for this reason, absent in early stage disease.

When a suspect hepatic focal lesion is identified in a patient undergoing long lasting AAS treatment, its further characterization is mandatory. The differential diagnosis may be difficult since HCC and hepatic adenoma (HCA), a benign liver tumor, can present similar clinical, radiological, and histological features. One way to differentiate the etiology is that benign lesions can reduce the size or even disappear upon AAS treatment cessation. ${ }^{(6,30,31)}$ If the nature of the hepatic focal lesion etiology cannot be determined, it is advisable to perform the surgical resection. A major concern is that HCA can undergo malignant transformation, presenting rapid or progressive tumor growth and/or tumor obstruction of the intrahepatic portal veins. Therefore, close monitoring of HCA lesions is mandatory.(16) Gorayski et al. and Solbach et al. found foci in hepatic lesions devoid of CD34-positive immunostaining, raising the possibility of malignant transformation within a pre-existing adenoma (HCA). ${ }^{10,13)}$ The best evidence available in the literature reports a frequency of malignant transformation in about $4.5-9 \%$ of HCA cases. ${ }^{(32,33)}$ However, if these statistics also hold true for HCC induced by AAS abuse is not known.

Routine abdominal imaging screening in healthy AAS users for performance improvement could be an alternative to detect early stage liver diseases, however, because the abnormal development of such lesions, a better strategy would be focusing on orientation to such population and warning them about the need of medical supervision.

Despite the limited data in the literature and the limitation of a study compiling a small number of cases, we would like to put forth the idea that unsupervised AAS usage is an emerging public health concern, as the population exposed to this practice is usually young, healthy and unaware of the potentially severe adverse events. Furthermore, evidence suggest an association between long term anabolic androgenic steroids abuse for physical performance improvement and hepatocarcinoma. 


\section{CONCLUSIONS}

Despite the limited evidence, there is some suggestion that hepatocarcinoma may be associated with anabolic-androgenic steroids abuse for performance improvement. AAS must be taken only under specia- lized supervision and public policies to make high risk populations aware of the risks of AAS misuse and self-administration should be pursued.

\section{REFERENCES}

1. Evert M, Dombrowski F. [Hepatocellular carcinoma in the non-cirrhotic liver]. Pathologe. 2008;29(1):4752. German.

2. Ferlay J, Shin HR, Bray F, Forman D, Mathers C, Parkin DM. Estimates of worldwide burden of cancer in 2008: GLOBOCAN 2008. Int J Cancer. 2010;127(12):2893-917.

3. Goodman ZD, Terracciano L (Burt AD, Portmann $B C$, Ferrell LD, editors). "Tumours and tumourlike lesions of the liver," In: MacSween's Pathology of the Liver. 5th ed. Philadelphia, Pa, USA: Churchill Livingstone; 2007. p. 761-814.

4. Sokal JE, Firat D. Fanconi's anemia and hepatic cirrhosis. Am J Med. 1965 ;39(3):464-75.

5. Velazquez I, Alter BP. Androgens and liver tumors: Fanconi's anemia and non-Fanconi's conditions. Am J Hematol. 2004;77(3):257-67.

6. Lüderwald S, Zinka B, Thieme D, Eisenmenger W."Misuse of anabolic androgenic steroids. Fatal cases in recreational bodybuilding. Rechtsmedizin. 2008;18(3):183-8.

7. Goldman A, Basaria S. Adverse health effects of androgen use. Mol Cell Endocrinol. 2017; 464:46-55.

8. Overly WL, Dankoff JA, Wang BK, Singh UD. Androgens and hepatocellular carcinoma in an athlete. Ann Intern Med. 1984;100(1):158-9.

9. Goldman B. Liver carcinoma in an athlete taking anabolic steroids. J Am Osteopath Assoc. 1985;85(2):56.

10. Gorayski P, Thompson CH, Subhash HS, Thomas AC. Hepatocellular carcinoma associated with recreational anabolic steroid use. Br J Sports Med. 2008;42(1):74-5.

11. Hardt A, Stippel D, Odenthal M, Hölscher AH, Dienes HP, Drebber U. Development of hepatocellular carcinoma associated with anabolic androgenic ste- roid abuse in a young bodybuilder: a case report. Case Rep Pathol. 2012; 2012:195607.

12. Kesler T, Sandhu RS, Krishnamoorthy S. Hepatology: hepatocellular carcinoma in a young man secondary to androgenic anabolic steroid abuse. J Gastroenterol Hepatol. 2014;29(11):1852.

13. Solbach P, Potthoff A, Raatschen HJ, Soudah B, Lehmann U, Schneider A et al. Testosterone-receptor positive hepatocellular carcinoma in a 29-year old bodybuilder with a history of anabolic androgenic steroid abuse: a case report. BMC Gastroenterol. 2015;15(1):60.

14. Wright JE. Anabolic steroids and athletics. Exerc Sport Sci Rev 1980; 8:149-202.

15. Pope HG Jr, Katz DL, Champoux R. Anabolic - androgenic steroid use among 1,010 college men. Phys Sportsmed. 1988;16(7):75-81.

16. Bahrke MS, Yesalis CE, Kopstein AN, Stephens JA. Risk factors associated with anabolic-androgenic steroid use among adolescents. Sports Med. 2000;29(6):397-405.

17. Buckley WE, Yesalis CE 3rd, Friedl KE, Anderson WA, Streit AL, Wright JE. Estimated prevalence of anabolic steroid use among male high school seniors. JAMA. 1988;260(23):3441-5.

18. Williamson DJ. Anabolic steroid use among students at a British college of technology. Br J Sports Med. 1993;27(3):200-1.

19. Nilsson S, Baigi A, Marklund B, Fridlund B. The prevalence of the use of androgenic anabolic steroids by adolescents in a county of Sweden. Eur J Public Health. 2001;11(2):195-7.

20. Johnson MD, Jay MS, Shoup B, Rickert VI. Anabolic steroid use by male adolescents. Pediatrics. 1989;83(6):921-4. 
21. van Amsterdam J, Opperhuizen A, Hartgens F. Adverse health effects of anabolic-androgenic steroids. Regul Toxicol Pharmacol. 2010;57(1):117-23.

22. Schwingel PA, Cotrim HP, Salles BR, Almeida CE, dos Santos CR Jr, Nachef B, et al. Anabolic-androgenic steroids: a possible new risk factor of toxicant-associated fatty liver disease. Liver Int. 2011;31(3):348-53.

23. Yeh SH, Chen PJ. Gender disparity of hepatocellular carcinoma: the roles of sex hormones. Oncology. 2010;78 Suppl 1:172-9.

24. Yu MW, Yang YC, Yang SY, Cheng SW, Liaw YF, Lin SM, et al. Hormonal markers and hepatitis B virus-related hepatocellular carcinoma risk: a nested case-control study among men. J Natl Cancer Inst. 2001;93(21):1644-51.

25. Yu MW, Cheng SW, Lin MW, Yang SY, Liaw YF, Chang HC, et al. Androgen-receptor gene CAG repeats, plasma testosterone levels, and risk of hepatitis B-related hepatocellular carcinoma. J Natl Cancer Inst. 2000;92(24):2023-8.

26. Toh YC. Effect of neonatal castration on liver tumor induction by $\mathrm{N}$-2-fluorenylacetamide in suckling BALB/c mice. Carcinogenesis. 1981;2(11):1219-21.

27. Ma WL, Hsu CL, Wu MH, Wu CT, Wu CC, Lai JJ, et al. Androgen receptor is a new potential therapeutic target for the treatment of hepatocellular carcinoma. Gastroenterology. 2008;135(3):947-55.

28. Chiu CM, Yeh SH, Chen PJ, Kuo TJ, Chang CJ, Chen $\mathrm{PJ}$, et al. Hepatitis $\mathrm{B}$ virus $\mathrm{X}$ protein enhances androgen receptor-responsive gene expression depending on androgen level. Proc Natl Acad Sci USA. 2007;104(8):2571-8.

29. Bond P, Llewellyn W, Van Mol P. Anabolic androgenic steroid-induced hepatotoxicity. Med Hypotheses. 2016;93:150-3.

30. Grazioli L, Olivetti L, Mazza G, Bondioni MP. MR Imaging of hepatocellular adenomas and differential diagnosis dilemma. Int J Hepatol. 2013;2013:374170.

31. Schlageter M, Terracciano LM, D'Angelo S, Sorrentino P. Histopathology of hepatocellular carcinoma. World J Gastroenterol. 2014;20(43):15955-64.

32. Fischer SE. Hepatocellular carcinoma arising in hepatic adenoma: diagnostic and management implications. Diagn Histopathol. 2014;20(6):257-61.

33. Stoot JH, Coelen RJ, De Jong MC, Dejong CH. Malignant transformation of hepatocellular adenomas into hepatocellular carcinomas: a systematic review including more than 1600 adenoma cases. HPB. 2010;12(8):509-22. 